Proceedings of the 3rd International Congress APMAS2013, April 24-28, 2013, Antalya, Turkey

\title{
Granite Based Glass-Ceramic Materials
}

\author{
G. BAYRAK ${ }^{a, *}$ AND S. YILMAZ ${ }^{b}$ \\ ${ }^{a}$ Sakarya University, Department of Welding Technology, Arifiye Vocational High School \\ 54580 Arifiye, Sakarya, Turkey \\ ${ }^{b}$ Sakarya University, Engineering Faculty, Department of Metallurgical and Materials Engineering \\ Esentepe Campus, 54187 Sakarya, Turkey
}

\begin{abstract}
In this study, production possibility of glass and glass-ceramic produced from granite was investigated. The composition of granite based glass bath mixture was $50 \mathrm{wt} \%$ granite, 25 wt\% dolomite and 25 wt\% sodium carbonate. Composition that was grounded and mixed in a ball mill for $2 \mathrm{~h}$ was melted at $1500^{\circ} \mathrm{C}$ for $1 \mathrm{~h}$. Glass samples were heat treated for crystallization to produce glass-ceramic materials at $800{ }^{\circ} \mathrm{C}, 900{ }^{\circ} \mathrm{C}$ and $1000{ }^{\circ} \mathrm{C}$ for $2 \mathrm{~h}$ to promote internal crystallization. Phase identifications of glass and glass-ceramic materials were investigated by X-ray diffraction analysis. Moreover, hardness and fracture toughness measurement of glass and glass-ceramic materials were applied. Granite based materials after that melting and casting process was found amorphous state by characterization with X-ray diffraction analysis. After the heat treatment processes, crystal phases settled out in glass matrix were also determined in granite based materials. Moreover, values of hardness and fracture toughness increasing were detected by heat treatment schedule.
\end{abstract}

DOI: $10.12693 /$ APhysPolA.125.623

PACS: 61.43.Fs, 62.20.-x, 61.05.cp

\section{Introduction}

Granite is an intrusive igneous rock which includes high amount of $\mathrm{SiO}_{2}$ (approximately $70 \mathrm{wt} \%$ ). This volcanic rock is the most common plutonic rock of the Earth crust, forming by the slowly cooling of magma (silicate melt) at depth $[1,2]$. The composition of granite is a suitable for production of glass and glass-ceramics. As known, glass-ceramics are polycrystalline solids prepared from glasses with controlled crystallization heat treatment process. This process is realized by subjecting suitable glasses to a carefully regulated heat treatment schedule which results in the nucleation and growth of crystal phases within the glass [3]. Glass-ceramics find many applications in industry due to their superior properties, namely corrosion and wear resistance [4]. There are a lot of materials including high content $\mathrm{SiO}_{2}, \mathrm{Al}_{2} \mathrm{O}_{3}$ and $\mathrm{CaO}$ etc. like basalt, gabbro, some slags (blast furnace, arc furnace, cupola furnace etc.). In addition, some industrial wastes like ashes can be used for glass-ceramic production successfully $[5,6]$.
The aims of the study were to investigate of production possibility of glass and glass-ceramic produced from granite and to determine of structural and mechanical properties of produced granite based glass-ceramics.

\section{Experimental procedure}

Granite rocks were obtained as chunks and crashing was carried out in a jaw and conic crushers. Then, it was milled using ring miller and sieved to the grids of $100 \mu \mathrm{m} .25 \mathrm{wt} \%$ sodium carbonate and $25 \mathrm{wt} \%$ dolomite were added to granite for glass bath composition.

The chemical analysis of the used raw materials in the study and the calculated chemical composition of the glass melt are given in Table. The prepared glass bath were mixed by using the alumina ball mill for $1 \mathrm{~h}$ and then were melted in $\mathrm{Al}_{2} \mathrm{O}_{3}$ crucible at $1500{ }^{\circ} \mathrm{C}$ for $1 \mathrm{~h}$ in an electrical furnace. The glass melt were casted to the graphite mold in bulk form and annealed at $600{ }^{\circ} \mathrm{C}$ for stress relief. The glasses were cooled down to room temperature at a rate of $3^{\circ} \mathrm{C} / \mathrm{min}$.

TABLE

Chemical analysis of the used raw materials and calculated chemical composition of the glass (wt\%).

\begin{tabular}{l|c|c|c|c|c|c|c|c|c|c|c}
\hline \hline Constituent oxides & $\mathrm{SiO}_{2}$ & $\mathrm{Al}_{2} \mathrm{O}_{3}$ & $\mathrm{MgO}$ & $\mathrm{CaO}$ & $\mathrm{Na}_{2} \mathrm{O}$ & $\mathrm{K}_{2} \mathrm{O}$ & $\mathrm{FeO}$ & $\mathrm{Fe}_{2} \mathrm{O}_{3}$ & $\mathrm{TiO}_{2}$ & $\mathrm{P}_{2} \mathrm{O}_{5}$ & $\mathrm{MnO}$ \\
\hline granite & 72.04 & 14.42 & 0.71 & 1.82 & 3.69 & 3.97 & 1.22 & 1.68 & 0.30 & 0.12 & 0.05 \\
sodium carbonate & 0.22 & 0.13 & - & - & 43.63 & - & - & - & - & - & - \\
dolomite & 0.30 & 0.24 & 36.97 & 62.39 & - & - & - & 0.02 & - & - & - \\
\hline \hline glass & 42.40 & 8.49 & 11.60 & 19.20 & 14.83 & 2.40 & 0.98 & 0.72 & 0.17 & 0.07 & 0.33
\end{tabular}

After casting process, it was seen that granite based

*e-mail: gunhanb@sakarya.edu.tr samples were determined as amorphous state confirmed by X-ray diffraction (XRD) analysis. Granite based glasses were subjected to crystallization heat treatment at 800,900 , and $1000^{\circ} \mathrm{C}$ for $2 \mathrm{~h}$ for glass-ceramic trans- 
formation from glassy amorphous state. The single-stage method for heat treatment was preferred to promote internal crystallization. Both heating and cooling processes of the samples were performed at a rate of $5^{\circ} \mathrm{C} / \mathrm{min}$ for heat treatment process. The crystalline phases in glass-ceramics were characterized by XRD analysis (Rigaku $\mathrm{D} / \mathrm{Max}$ which has a wavelength of $1.54056 \AA$ with a $\mathrm{Cu} K_{\alpha}$ radiation. Scanning electron microscopy (SEM, JEOL 6060) was employed for microstructure observations. The mechanical properties were evaluated by Vickers microhardness indenter (Leitz), load of $15 \mathrm{gf}$; each value is the mean value of measurements made with five samples, with 10 indentations for each sample. The fracture toughness of the glass and glass-ceramics were determined by the indentation technique. Polished specimens were indented at 5 separated locations. The test conditions are determined as $0.5 \mathrm{~N}$ test load for $20 \mathrm{~s}$. The calculations formula used in the study was given in Eq. (1) $[7,8]$ :

$$
K_{\mathrm{IC}}=0.0824 \frac{P}{c^{3} / 2} \text {. }
$$

\section{Results and discussion}

XRD analysis was performed to determine the crystalline phases. The XRD analyses of granite based glass and glass-ceramics were given in Figs. 1 and 2. It is clear from Fig. 1 that granite based glass sample was glassy amorphous state.

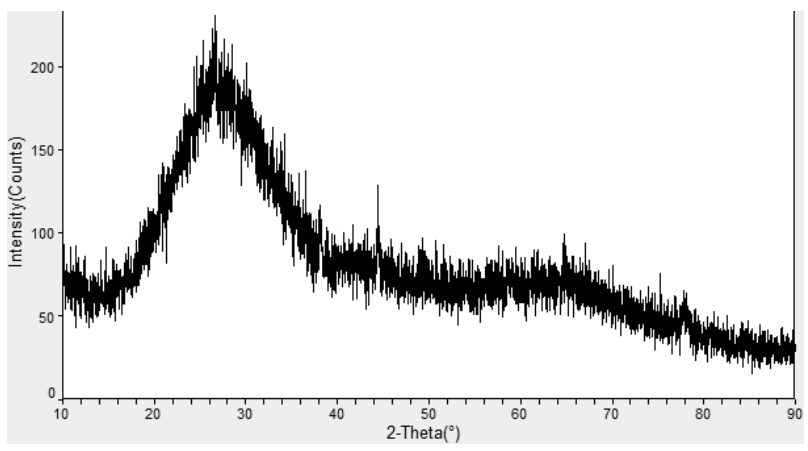

Fig. 1. XRD pattern of the granite based glass.

In order to determine the crystalline phases, XRD analysis were also carried out on glass-ceramic samples. The phases identified in the glass-ceramic samples are akermanite $\left[\mathrm{Ca}_{2} \mathrm{MgSiO}_{7}\right]$, sodium aluminum silicate $\left[\mathrm{NaAlSiO}_{4}\right]$, combeite $\left[\mathrm{Na}_{4} \mathrm{Ca}_{4} \mathrm{Si}_{6} \mathrm{O}_{18}\right]$, and nepheline $\left[\mathrm{Na}_{3} \mathrm{~K}\left(\mathrm{Si}_{0.56} \mathrm{Al}_{0.44}\right)_{8} \mathrm{O}_{16}\right]$ at $800^{\circ} \mathrm{C}$ heat treatment process seen in Fig. 2. When melilite $\left[\mathrm{Ca}_{8} \mathrm{Al}_{2} \mathrm{Mg}_{3} \mathrm{Si}_{7} \mathrm{O}_{28}\right]$, akermanite, and nepheline phases were detected in granite based glass-ceramic at $900{ }^{\circ} \mathrm{C}$ heat treatment, akermanite, andalusite $\left[\mathrm{Al}_{2}\left(\mathrm{SiO}_{4}\right) \mathrm{O}\right]$, sodium aluminum silicate and nepheline phases were determined glass-ceramic heat treated at $1000^{\circ} \mathrm{C}$. These phases are common crystalline phases in glass-ceramics [3, 9]. Presence of these phases showed that glass-ceramic transformation realized from amorphous glass structure. The increase in heat treatment temperature affects the crystalline phases in glass-ceramics due to the more efficient diffusion mechanism in high temperatures (see Fig. 2, next page).

Figure 3 shows the values of microhardness and fracture toughness of granite based glass and glass-ceramics. The results indicated that the hardness and fracture toughness of the glass-ceramic materials are higher than the glass materials. They increase depending on heat treatment temperature and glass-ceramic transformation (Fig. 3).
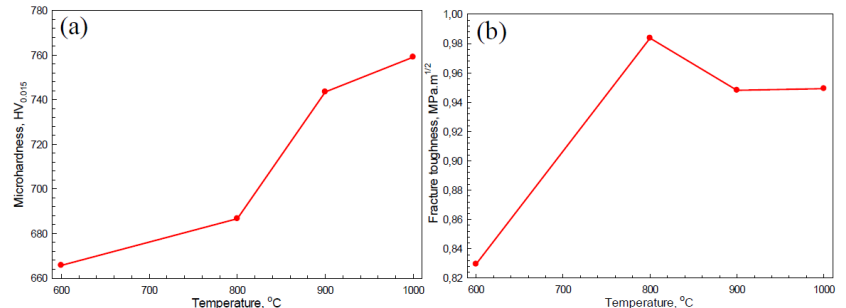

Fig. 3. Hardness and fracture toughness graphics of glass and glass-ceramics: (a) hardness, (b) fracture toughness.

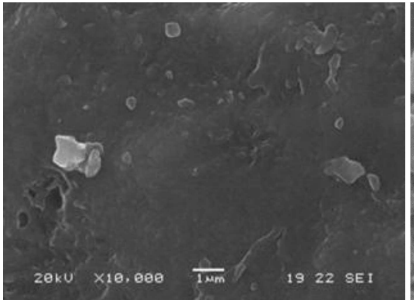

$800{ }^{\circ} \mathrm{C}$

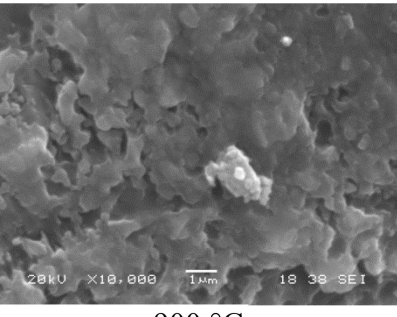

$900{ }^{\circ} \mathrm{C}$
Fig. 4. SEM microstructures of the granite based glass-ceramics.

Figure 4 shows SEM microstructures of the granite based glass-ceramics. As seen in the microstructure, there are crystalline phases in the glass matrix. Increase in heat treatment temperature caused forming a more dense and crystalline structure.

\section{Summary}

In this study, the natural magmatic granite rock material was employed to produce glass and glass-ceramic materials. The composition of granite based glass bath mixture was $50 \mathrm{wt} \%$ granite, $25 \mathrm{wt} \%$ dolomite and $25 \mathrm{wt} \%$ sodium carbonate. The structure was detected by XRD as amorphous before the heat treatment process. Granite based glasses were subjected to controlled crystallization heat treatment at 800,900 , and $1000^{\circ} \mathrm{C}$ and $2 \mathrm{~h}$ for glass-ceramic transformation from glassy amorphous state. Akermanite, sodium aluminum silicate, andalusite, nepheline, combeite, melilite, and forsterite phases were determined after the heat treatment process. Providing better crystallization conditions via 
higher heat treatment temperatures has a positive effect on hardness. As an expected result of this situation, fracture toughness results decreased. In the SEM microstructure, crystalline phases dispersed in the glass matrix. Increase in heat treatment temperature caused more crystalline structure.

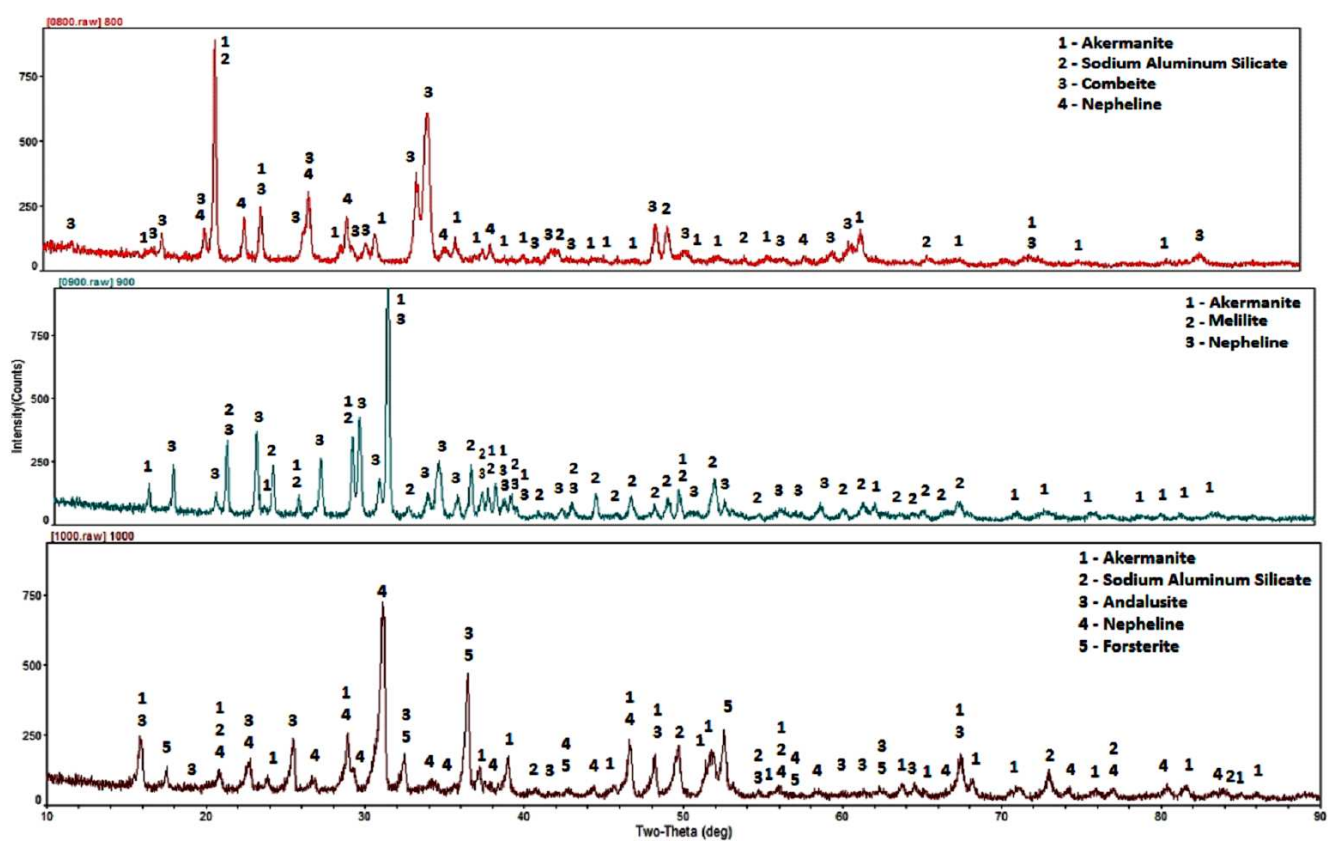

Fig. 2. XRD patterns of the granite based glass-ceramics.

\section{Acknowledgments}

The authors would like to express their gratitude to Sakarya University Engineering Faculty, and Prof. Hatem Akbulut, the head of the Department of Metallurgy and Material Engineering for supporting this work. The authors are also grateful to Kemal Ergin for assisting experimental assistance.

\section{References}

[1] G.W. Tyrrell, The Principal of Petrology, Chapman and Hall, New York 1971.

[2] G. Bayrak, Ph.D. Thesis, Sakarya University, 2009.

[3] P.W. Mc Millan, Glass-Ceramics, Academic Press, New York 1971.
[4] S. Yilmaz, O.T. Ozkan, V. Gunay, Ceram. Int. 27, 477 (1997).

[5] M. Erol, S. Kucukbayrak, A.E. Mericboyu, Fuel 86 , 706 (2007).

[6] G. Bayrak, S. Yilmaz, Ceram. Int. 32, 441 (2006).

[7] G. Bolelli, L. Lusvarghi, T. Manfredini, E. Parsini, C. Siligardi, J. Europ. Ceram. Soc. 27, 4575 (2007).

[8] V. Gunay, S. Hampshire, J. Mater. Proc. Technol. 54, 348 (1995).

[9] J.D. Eusden, T.T. Eighmy, K. Hockert, E. Holland, K. Marsella, Appl. Geochem. 14, 1073 (1999). 